\title{
Purification and characterization of thermophilin ST-1, a novel bacteriocin produced by Streptococcus thermophilus ACA-DC 0001
}

\author{
Anastasios AKTYPIS*, George KALANTZOPOULOS \\ Laboratory of Dairy Research, Department of Food Science and Technology, \\ Agricultural University of Athens, Iera Odos 75, 118 55, Athens, Greece
}

Received 9 January 2003 - Accepted 24 April 2003

Published online 22 September 2003

\begin{abstract}
Thermophilin ST-1 is produced by Streptococcus thermophilus ACA-DC 0001, a "wild" strain isolated from traditional Greek yogurt products. It exerts an inhibitory effect on lactic acid bacteria, several food spoilage and food-borne pathogenic microorganisms, and some Gramnegative phytopathogen bacteria, including Listeria innocua BL 86/20. Enterococcus faecalis EF1, Staphylococcus aureus ATCC 29996, Xanthomonas campestris BPIC 1660, Pseudomonas syringae BPIC 1549 and Erwinia rubrifasciens BPIC 1710. The crude antimicrobial compound is heat-labile $\left(60^{\circ} \mathrm{C}\right.$ for $\left.10 \mathrm{~min}\right)$ and sensitive to the proteolytic enzymes pronase and trypsin and high acidic and alkaline conditions, and shows a bactericidal mode of action against the indicator strain Lactococcus lactis ssp. cremoris CNRZ-117. Production of thermophilin ST-1 starts during the early growth of the producer strain and reaches a maximum titer of $2560 \mathrm{AU} \cdot \mathrm{mL}^{-1}$ at the end of the exponential growth. Thermophilin ST-1 was partially purified by ammonium sulfate precipitation, ionexchange and size-exclusion chromatography. SDS-PAGE electrophoresis of purified thermophilin ST-1 showed a single protein band with a molecular mass of $30 \mathrm{~kg} \cdot \mathrm{mol}^{-1}$, classifying this novel bacteriocin with the large heat-labile proteins. Until now, however, the molecular mass of bacteriocins reported in the species of $S$. thermophilus was less than $10 \mathrm{~kg} \cdot \mathrm{mol}^{-1}$ (small, heat-stable peptides). Curing experiments did not result in the loss of bacteriocin production, suggesting that the genetic determinant is probably located on the chromosome.
\end{abstract}

Streptococcus thermophilus / bacteriocin / thermophilin / lactic acid bacteria / antimicrobial activity / phytopathogen

Résumé - Purification et caractérisation de la thermophiline ST-1, une nouvelle bactériocine produite par Streptococcus thermophilus ACA-DC 0001. La thermophiline ST-1 est une bactériocine produite par Streptococcus thermophilus ACA-DC 0001, une souche «sauvage» isolée d'un yaourt traditionnel Grec. Elle présente un large spectre d'activité contre les germes pathogènes alimentaires ainsi que contre certaines bactéries Gram-négatives phytopathogènes. Elle inhibe, non seulement, des bactéries lactiques mais également, les souches Listeria innocua BL 86/20, Enterococcus faecalis EF1, Staphylococcus aureus ATTC 29996, Xanthomonas campestris BPIC 1660, Pseudomonas syringae BPIC 1549 et Erwinia rubrifasciens BPIC 1710, ainsi que la souche indicatrice Lactococcus lactis ssp. cremoris CNRZ-117. L'extrait brut antimicrobien est sensible aux enzymes protéolytiques pronase et trypsine, à la température de $60{ }^{\circ} \mathrm{C}$ après $10 \mathrm{~min}$ et aux conditions très acides et très alcalines. La production de la thermophiline commence dès le début de

\footnotetext{
*Corresponding author: idte4aka@ aua.gr
} 
la phase de croissance et atteint son niveau maximum d'activité de $2560 \mathrm{AU} \cdot \mathrm{mL}^{-1}$ à la fin de la phase exponentielle. Elle a été partiellement purifiée après précipitation au sulfate d'ammonium, chromatographie d' échange d'ions et ensuite chromatographie d'exclusion stérique. Sa masse moléculaire apparente est d'environ $30 \mathrm{~kg} \cdot \mathrm{mol}^{-1}$. L'électrophorèse SDS-PAGE de la thermophiline ST-1 purifiée présentait une seule bande avec une masse moléculaire de $30 \mathrm{~kg} \cdot \mathrm{mol}^{-1}$, classant cette nouvelle batériocine sous les protéines de haut poids moléculaire et thermolabiles. Jusqu'à présent, la masse moléculaire des bactériocines retrouvées dans les différentes espèces de $S$. thermophilus était inférieure à $10 \mathrm{~kg} \cdot \mathrm{mol}^{-1}$ (petites peptides stables à haute température). De récents essais de cure ont montré une stabilité génétique de la production de la bactériocine, suggérant une localisation probable du gène codant pour la thermophiline ST-1 sur le chromosome.

Streptococcus thermophilus / bactériocine / thermophiline / bactérie lactique / activité antimicrobienne / phytopathogène

\section{INTRODUCTION}

Due to the general tendency to decrease the use of chemical additives in foodstuffs, current research is mainly focused on the use of naturally-occuring metabolites produced by selected bacteria to inhibit the growth of undesirable microorganisms. Among the different types of antagonistic compounds produced by lactic acid bacteria, bacteriocins have gained increasing interest as biological food preservatives. Bacteriocins are proteinaceous compounds that inhibit mainly closely related species. Their inhibitory spectrum is restricted to Gram-positive bacteria, but several bacteriocins produced by lactic acid bacteria are also active against food spoilage and foodborne pathogenic microorganisms including Bacillus cereus, Clostridium botulinum, C. perfringens, Listeria monocytogenes, Staphylococcus aureus, Escherichia coli, Enterobacteria, etc. [2, 3, 23, 28, 31]. The above bacteriocins are the most important with regard to food preservation and the development of probiotics. However, the production of bacteriocins that are only active against other lactic acid bacteria could also play a role in the development of starter cultures, since these strains may be used to suppress the growth of nonstarter lactic acid bacteria. In addition, Visser et al. [37], have shown that a variety of lactic acid bacteria, isolated from plant surfaces and plant-associated products, were antagonistic to the test strains of the Gramnegative phytopathogens Xanthomonas campestris, Pseudomonas syringae and Erwinia carotovora.

Numerous reports on bacteriocins from lactic acid bacteria (LAB) are available, and the literature has been reviewed extensively in recent years [10, 12, 20, 26, 32]. However, most papers deal with bacteriocins produced by various lactococci, pediococci, leuconostoc and enterococci, and relatively little is known about bacteriocins from Streptococcus thermophilus species.

Streptococcus thermophilus is an important dairy starter culture, which is involved in the large-scale production of yogurt and certain cheese varieties, including Feta cheese, in association with other thermophilic strains [33]. The ability of various $S$. thermophilus strains to produce several antibacterial agents has been studied in the past $[1,5,18,24,36,38]$. The aim of this study was to purify and characterize a new bacteriocin produced by the "wild" strain S. thermophilus ACA-DC 0001, isolated from traditional Greek yogurt.

\section{MATERIALS AND METHODS}

\subsection{Bacterial cultures and media}

The producer strain $S$. thermophilus ACA-DC 0001 originated from the culture 
collection of the Agricultural University of Athens (ACA-DC), and was isolated from traditional yogurt using sheep milk. The sensitive strains originated from the ECBRIDGE T-Project on the Biotechnology of Lactic Acid Bacteria [30], the culture collection of the Agricultural University of Athens (ACA-DC), the Greek Pasteur Institute and the Collection of the Benaki Phytopathological Institute of Athens (BPIC). All strains were maintained as frozen stocks at $-80^{\circ} \mathrm{C}$ by the "Protect Bacterial Preservers" TS/70-A system (STC Co., Lancashire, UK).

The liquid media used were Elliker broth (Biokar, Beauvais, France) for the producer strain $S$. thermohilus ACA-DC 0001, M17 broth (Biokar) for lactococci and streptococci, MRS broth (Biokar) for lactobacilli, BHI broth (Biokar) for enterococci, listeria and staphylococci, RCM broth (Biokar) for clostridia and nutrient broth (Biokar) for phytopathogenic bacteria.

\subsection{Culture extract preparation and bacteriocin assays}

To demonstrate the presence of antimicrobial activity in the culture broths of S. thermophilus ACA-DC 0001, an agar well diffusion test (ADT) was used based on the assay method described by Tagg et al. [29]. Before testing, cells were removed by centrifugation and the supernatant was neutralized with $1.0 \mathrm{~mol} \cdot \mathrm{L}^{-1} \mathrm{NaOH}$ and filter sterilized with a $0.22 \mu \mathrm{m}$, Millex-GV filter (Millipore Co., Bedford, MA, USA). The resulting material is referred to as "crude bacteriocin". Wells $6 \mathrm{~mm}$ in diameter were cut into the agar media, containing about $10^{6} \mathrm{cfu} \cdot \mathrm{mL}^{-1}$ of the sensitive strain, by using a cork borer and then $50 \mu \mathrm{L}$ of crude bacteriocin were placed into each well. The plates were placed at $4{ }^{\circ} \mathrm{C}$ for $2 \mathrm{~h}$ for crude bacteriocin diffusion, then incubated at the appropriate temperature for each sensitive strain and examined for zones of inhibition. For the bacteriocin titer determination a modification of the critical dilution assay was used [6]. Serial two-fold dilutions were made and $50 \mu \mathrm{L}$ from each dilution were placed in wells in plates seeded with the sensitive strain. The titer was defined as the reciprocal of the highest dilution exhibiting inhibition of the sensitive strain, and was expressed in arbitrary units (AU) per milliliter. Due to the extensive range between two serial dilutions of the critical dilution assay, we also tested the intermediate between the higher and following dilution in order to be more accurate in the bacteriocin titer estimation. L. lactis $\mathrm{ssp}$. cremoris CNRZ 117 was routinely used as the target organism at $30^{\circ} \mathrm{C}$. For the determination of the inhibition spectrum of crude bacteriocin, several sensitive strains were used with the agar well diffusion test, using the appropriate agar media and incubation conditions for their growth (Tab. I).

\subsection{Kinetics of growth and bacteriocin production}

Elliker broth medium was chosen for bacteriocin production studies, taking into consideration the data of Geis et al. [8] and Piard et al. [21] for higher bacteriocin production from lactic streptococci. Elliker broth medium $(100 \mathrm{~mL})$ was inoculated with $1 \mathrm{~mL}$ from a 16-h culture of $S$. thermophilus ACA-DC 0001 and incubated at $37^{\circ} \mathrm{C}$, without agitation. At appropriate intervals, samples were removed for measurement of optical density (OD) at $600 \mathrm{~nm}$ and bacteriocin activity, as previously described.

\subsection{Properties of crude bacteriocin}

For a preliminary determination of the size of the bacteriocin produced by $S$. thermophilus ACA-DC 0001, $50 \mathrm{~mL}$ supernatant was subjected to ultrafiltration through a series of Diaflo membranes (Amicon Co., Lexington, MA, USA). The diaflo membranes employed included XM300, XM100, XM50, YM30 and YM10. The volumes of retentates and filtrates were recorded and the bacteriocin titers were determined. 
Table I. Antimicrobial spectrum of crude bacteriocin from S. thermophilus ACA-DC 0001.

\begin{tabular}{|c|c|}
\hline Sensitive strains & $\begin{array}{l}\text { Inhibition } \\
\text { zone (mm) }\end{array}$ \\
\hline L. lactis ssp. lactis ACA-DC $127 *$ & 11 \\
\hline L. lactis ssp. cremoris CNRZ $117 *$ & 15 \\
\hline Lb. delbrueckii ssp. bulgaricus ATCC $11842 *$ & - \\
\hline Lb. delbrueckii ssp. bulgaricus ACA-DC 0085 & $(8) \ddagger$ \\
\hline Lb. delbrueckii ssp. bulgaricus ACA-DC 0086 & $(9) \ddagger$ \\
\hline Lb. delbrueckii ssp. bulgaricus ACA-DC 0100 * & - \\
\hline Lb. delbrueckii ssp. bulgaricus ACA-DC 0104 * & - \\
\hline Lb. fermentum ATCC $9338 *$ & - \\
\hline S. thermophilus ST $20 \dagger$ & 10 \\
\hline S. thermophilus ST $112 \dagger$ & 9 \\
\hline C. sporogenes $\mathrm{C} 22 / 10 \dagger$ & - \\
\hline C. tyrobutyricum NCDO $1754 \dagger$ & - \\
\hline E. faecalis ATCC 10741 & 11 \\
\hline E. faecalis $\mathrm{EF} 1 \dagger$ & 11 \\
\hline L. innocua $\mathrm{BL} 86 / 26 \dagger$ & 11 \\
\hline S. aureus ATCC 29996 & 10 \\
\hline S. carnosus $\mathrm{MC} 1 \dagger$ & - \\
\hline Xanthomonas campestris pv. graminis BPIC $1660 \S$ & 11 \\
\hline Erwinia rubrifasciens BPIC $1710 \S$ & 9 \\
\hline Pseudomonas syringae pv. pisi BPIC $1549 \S$ & 8 \\
\hline
\end{tabular}

* strains from ACA-DC Culture Collection; $\uparrow$ strains from TNO Culture Collection; $\S$ strains from Benaki Phytopathological Institute of Athens; $\$$ fade zone of partial inhibition; - no inhibition, diameter of well is $6 \mathrm{~mm}$.

The data represent the diameter of the inhibition zone observed, using the agar diffusion test with several sensitive strains as bioassay strains.

Samples of crude bacteriocin (2560 AU.mL ${ }^{-1}$ ) were examined for susceptibility to proteolytic and other enzymes. The following enzymes $\left(1 \mathrm{mg} \cdot \mathrm{mL}^{-1}\right)$ and respective buffers were employed: pronase $\mathrm{E}$, trypsin, $\alpha$-chymotrypsin proteinase $\mathrm{K}$, rennin and lysozyme in $0.01 \mathrm{~mol} \cdot \mathrm{L}^{-1}$ sodium phosphate ( $\mathrm{pH} 7.0$ ); ficin in $0.02 \mathrm{~mol} \cdot \mathrm{L}^{-1}$ cysteine hydrochloride, 0.01 disodium EDTA, $0.15 \mathrm{~mol} \cdot \mathrm{L}^{-1} \mathrm{NaCl}(\mathrm{pH} 7.0$ ); pepsin in $0.02 \mathrm{~mol} \cdot \mathrm{L}^{-1} \mathrm{HCl}$; proteinase- $\mathrm{K}$ in $0.1 \mathrm{~mol} \cdot \mathrm{L}^{-1}$ sodium acetate, $0.005 \mathrm{~mol} \cdot \mathrm{L}^{-1}$ calcium acetate $(\mathrm{pH} 7.5) ; \alpha$-amylase in $0.01 \mathrm{~mol} \cdot \mathrm{L}^{-1}$ potassium sulphate $(\mathrm{pH} 7)$ all the above enzymes from Sigma Aldrich Co. (St Louis, MO, USA) - and lipase (Serva $\mathrm{GmbH}$, Heidelberg, Germany) in $0.1 \mathrm{~mol} \cdot \mathrm{L}^{-1}$ potassium sulphate ( $\mathrm{pH}$ 6.0). Crude bacteriocin was mixed with equal volumes of the enzymatic solutions and incubated at $37^{\circ} \mathrm{C}$ for $1 \mathrm{~h}$, after which the remaining activity was determined by the agar diffusion method described previously. As a control, bacteriocin with added respective 
buffer solution was treated in the same manner as the test preparations.

Samples of crude bacteriocin (2560 AU.mL $\mathrm{mL}^{-1}, \mathrm{pH} 5.5$ ) were adjusted to $\mathrm{pH}$ values in the range of $1-12$ using $1.0 \mathrm{~mol} \cdot \mathrm{L}^{-1} \mathrm{HCl}$ or $1.0 \mathrm{~mol} \cdot \mathrm{L}^{-1} \mathrm{NaOH}$. After storage at $4{ }^{\circ} \mathrm{C}$ for $24 \mathrm{~h}$, the samples were neutralized and the remaining antimicrobial activities were measured by the ADT method. An equal to the respective amount of the $\mathrm{HCl}$ and $\mathrm{NaOH}$ ratio of Ringer solution was added to the samples as a control, taking into consideration the dilution of the bacteriocin titer during the $\mathrm{pH}$ adjustment of the samples.

Aliquots of the crude bacteriocin were subjected to two different heat treatments, at $50{ }^{\circ} \mathrm{C}$ and $60{ }^{\circ} \mathrm{C}$ for $10 \mathrm{~min}$, respectively. The remaining bacteriocin activity was determined by the ADT assay.

Finally, sterile supernatant fluid was stored at $25{ }^{\circ} \mathrm{C}, 4{ }^{\circ} \mathrm{C}$ and $-30{ }^{\circ} \mathrm{C}$. At different time intervals, samples were taken from the stored material for determination of the remaining activity.

\subsection{Mode of action of bacteriocin}

To study the effect on actively growing cells, the bioassay strain $L$. lactis ssp. cremoris CNRZ 117 was grown in M17 broth at $30^{\circ} \mathrm{C}$, and during the logarithmic phase various concentrations of crude bacteriocin were added. During this experiment, samples were taken and the optical density at $600 \mathrm{~nm}$ and number of colony forming units $\left(\mathrm{cfu} \cdot \mathrm{mL}^{-1}\right)$ were determined. The cfu of L. lactis ssp. cremoris CNRZ 117 were determined by plating appropiate dilutions on M17 agar followed by overnight incubation at $30{ }^{\circ} \mathrm{C}$.

To study the effect on stationary phase bacteria, cells of the bioassay strain from the stationary growth phase were used to test the viability against the bacteriocin. L. lactis ssp. cremoris CNRZ 117 cells $(2.5 \times$ $\left.10^{7} \mathrm{cfu} \cdot \mathrm{mL}^{-1}\right)$, taken from a 18 -h culture, were prepared in sodium phosphate buffer $5 \mathrm{mmol} \cdot \mathrm{L}^{-1}$ (pH 6.2). Sterilized concen- trated crude bacteriocin was added to the cell suspensions to give titers ranging from 320 to $10240 \mathrm{AU} \cdot \mathrm{mL}^{-1}$. The suspensions were incubated at $30^{\circ} \mathrm{C}$. At intervals of 5 , 30, 60 and 90 min samples were taken and cells were removed by centrifugation at $12000 \times g$ for $5 \mathrm{~min}$, washed twice with the phosphate buffer, and finally, the cell viability was determined by counting the colony forming units $\left(\mathrm{cfu} \cdot \mathrm{mL}^{-1}\right)$. Surviving cells were enumerated on M17 agar as described previously.

\subsection{Purification procedure}

S. thermophilus strain ACA-DC 0001 was grown in $1 \mathrm{~L}$ of Elliker broth at $37^{\circ} \mathrm{C}$ to stationary phase without agitation. The cells were removed by centrifugation at $10000 \times g$ for $15 \mathrm{~min}$, and the cell-free supernatant was used as starting material for bacteriocin purification (fraction I). All the purification steps were performed at $4{ }^{\circ} \mathrm{C}$.

\subsubsection{Ammonium sulfate precipitation}

Ammonium sulfate was added to a final concentration of $50 \%(\mathrm{wt} / \mathrm{vol})$, and stirring continued for $3 \mathrm{~h}$ at $4{ }^{\circ} \mathrm{C}$. The precipitate was collected by centrifugation at $10000 \times g$ for $30 \mathrm{~min}$ and redissolved in $20 \mathrm{~mL}$ of buffer A $\left(20 \mathrm{mmol} \cdot \mathrm{L}^{-1}\right.$ Bis-Tris buffer, $\mathrm{pH}$ 7.5) (fraction II).

\subsubsection{Ion-exchange chromatography}

Fraction II was desalted by dialysis with a Spectra/Por-5 dialysis membrane (Spectrum Laboratories, Los Angeles, CA, USA) with a molecular mass cut-off of $12 \mathrm{~kg} \cdot \mathrm{mol}^{-1}$ against $5 \mathrm{~L}$ of buffer $\mathrm{A}$ for $18 \mathrm{~h}$ at $4{ }^{\circ} \mathrm{C}$. The final volume of dialysate was $50 \mathrm{~mL}$. The bacteriocin preparation was subsequently applied to a sepharose QHP 16/10 anion-exchange column (Pharmacia, Uppsala, Sweden) equilibrated with buffer A using a Pharmacia FPLC system. The flowthrough fraction III containing bacteriocin activity 
was pooled and concentrated by ultrafiltration through a Diaflo membrane YM30 to a volume of $5 \mathrm{~mL}$. The ultrafiltrate was rediluted with $20 \mathrm{~mL}$ sodium acetate (20 mmol. $\mathrm{L}^{-1}, \mathrm{pH} 5$ ). This twice-repeated procedure resulted in a final $10 \mathrm{~mL}$ bacteriocin concentrate in sodium acetate solution $\left(5 \mathrm{~mol} \cdot \mathrm{L}^{-1}, \mathrm{pH} 5\right)$. The preparation was applied to a mono-S HR 16/10 cationexchange column (Pharmacia) equilibrated with sodium acetate solution $5 \mathrm{~mol} \cdot \mathrm{L}^{-1}$, pH 5. The activity was eluted with a continuous gradient of $2 \mathrm{~mol} \cdot \mathrm{L}^{-1} \mathrm{NaCl}$ in the same acetate buffer $\left(5 \mathrm{~mol} \cdot \mathrm{L}^{-1}, \mathrm{pH} 5\right.$, buffer B) using a FPLC system.

\subsubsection{Size-exclusion chromatography}

The active fractions eluted from the cationexchange chromatography were applied to a Superose 12 HR10/30 column (Pharmacia) equilibrated with sodium acetate solution $\left(20 \mathrm{mmol} \cdot \mathrm{L}^{-1}\right.$ ) containing $0.2 \mathrm{~mol} \cdot \mathrm{L}^{-1} \mathrm{NaCl}$, pH 5. Blue dextran 2000 was used to calibrate the column. The following molecular weight reference proteins were used: thyroglobulin (665000), ferritine (440 000), catalase (232000), aldolase (158000), dimerbovine serum albumin (134000), bovine serum albumin (67000), ovalbumin (45000), chymotrypsinogen (25000), ribonuclease (13 700) and cytochrome C (11 500). The flow rate was $1 \mathrm{~mL} \cdot \mathrm{min}^{-1}$ and $1 \mathrm{~mL}$ fractions were collected and assayed for absorbance at $280 \mathrm{~nm}$ and inhibition activity. The titer of each active fraction was determined.

\subsection{Protein determination}

Protein concentrations of the fractions were determined by the Bicinchoninic acid (BCA) assay using the Tiertek Multiscan system at $540 \mathrm{~nm}$ [22].

\subsection{SDS-PAGE Electrophoresis}

SDS-Polyacrylamide gel electrophoresis (PAGE), in the presence of SDS and $\beta$-mercaptoethanol and a Tricine buffer system, was used to monitor the purification steps of the bacteriocin and to determine the molecular mass of the purified thermophilin ST-1 [11, 27]. Polyacrylamide and $\mathrm{N}, \mathrm{N}$-methylenebisacrylamide concentrations were, respectively, 4 and $0.5 \%$ in the stacking gel, 10 and $0.5 \%$ in the spacer gel and 12 and $0.5 \%$ in the separating gel.

\subsection{Plasmid analysis and curing experiments}

Plasmid DNA was isolated from the lactic cultures grown in Elliker broth with $40 \mathrm{mmol} \cdot \mathrm{L}^{-1} \mathrm{dl}$-threonine at $37^{\circ} \mathrm{C}$ for $18 \mathrm{~h}$ following the protocol described by Maniatis et al. [16]. Isolated plasmid DNA was visualized following electrophoresis in $0.8 \%(\mathrm{w} / \mathrm{v})$ agarose gels in Tris-borate buffer at $30 \mathrm{~V}$ for $15 \mathrm{~h}$, and staining with ethidium bromide solution $\left(0.5 \mu \mathrm{g} \cdot \mathrm{mL}^{-1}\right)$. Escherichia coli V517 containing marker plasmids employed as a single source of covalently closed circular (ccc) DNA molecules of different size [17].

The process of plasmid curing followed the protocol described by Caro et al. [4]. Bacteria were incubated for $24 \mathrm{~h}$ at $43{ }^{\circ} \mathrm{C}$ in Elliker broth without glycerophosphate in the presence of acriflavine $\left(20 \mu \mathrm{g} \cdot \mathrm{mL}^{-1}\right)$. The cultures were serially diluted and spread onto Elliker broth agar and then incubated until small colonies were formed $(48 \mathrm{~h})$. Plates were then overlaid with semi-solid agar seeded with L. lactis ssp. cremoris CNRZ 117 as the indicator strain and incubated for an additional $24 \mathrm{~h}$ at $30^{\circ} \mathrm{C}$. Colonies were studied for the absence of a zone inhibition, indicating phenotypic loss of the $\left(\mathrm{Bac}^{+}\right)$trait.

\section{RESULTS}

\subsection{Antimicrobial spectrum}

The crude bacteriocin of $S$. thermophilus ACA-DC 0001 showed inhibition of a wide range of LAB strains of different species and other non-LAB strains. The susceptibility 


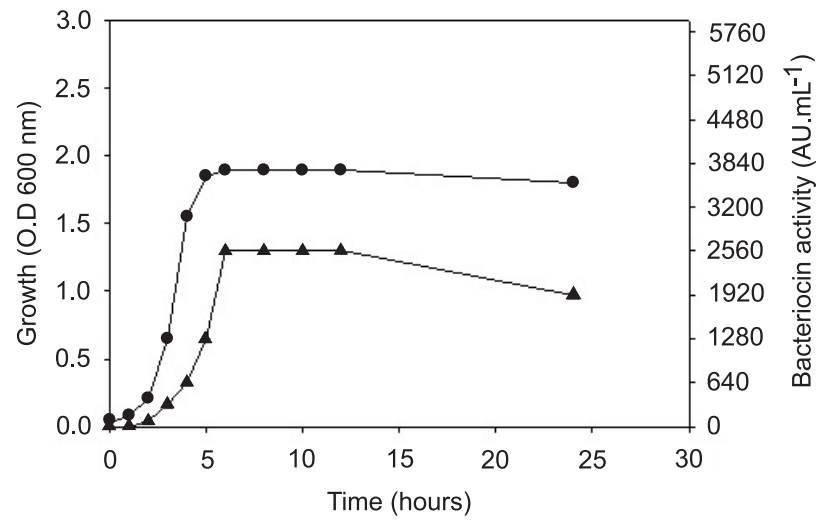

Figure 1. Production of thermophilin ST-1 during growth of $S$. thermophilus ACA-DC 0001. (•) Optical density at $600 \mathrm{~nm}$; and $(\mathbf{A})$ activity of thermophilin ST-1 in $\mathrm{AU} \cdot \mathrm{mL}^{-1}$. of representative strains is shown in Table $\mathrm{I}$. Lb. delbrueckii ssp. bulgaricus strains were not inhibited by the antimicrobial substance; however, three of them showed a zone of partial clearing. On the contrary, all the L. lactis and S. thermophilus strains were strongly inhibited. The most notable antimicrobial activity was found against food spoilage and pathogenic bacteria, such as Enterococcus faecalis EF1, E. faecalis ATCC 1074, Listeria innocua BL 86/26 and Staphylococcus aureus ATCC 29996 (Tab. I). However, the antimicrobial activity of bacteriocin was not restricted to Grampositive bacteria, but also included some Gram-negative phytopathogenic bacteria such as Xanthomonas campestris pv. graminis BPIC 1660, Erwinia rubrifasciens BPIC 1710 and Pseudomonas syringae pv. pisi BPIC 1549.

\subsection{Thermophilin ST-1 production}

The excretion of thermophilin ST-1 into the growth medium started early in the exponential growth phase (after $2 \mathrm{~h}$ of incubation) and reached a maximum titer of $2560 \mathrm{AU} \cdot \mathrm{mL}^{-1}$ after $6 \mathrm{~h}$ of incubation. During the stationary phase, after $24 \mathrm{~h}$ of fermentation, the bacteriocin activity decreased to $1920 \mathrm{AU} \cdot \mathrm{mL}^{-1}$ (Fig. 1).

\subsection{Properties of crude bacteriocin}

During preliminary ultrafiltration studies of crude bacteriocin, $80 \%$ of the activity was retained by the YM30 Diaflo membrane (cut-off $30 \mathrm{~kg} \cdot \mathrm{mol}^{-1}$ ). Only $2.5 \%$ of the activity passed through the membrane to the filtrate and about $17.5 \%$ was lost on the membrane (data not shown).

We tested the crude bacteriocin sensitivity (loss of activity) to various enzymes, different $\mathrm{pH}$ levels, heat treatments and preservation. The antimicrobial activity was inactivated only with the proteolytic enzymes pronase and trypsin (Tab. II).

Crude bacteriocin was found to be stable at around $\mathrm{pH} 6$ and completely inactivated at $\mathrm{pH}$ values between 1 and 3 and 10 and 12 . The crude bacteriocin was very sensitive to heat treatment and completely lost its activity after exposure for $10 \mathrm{~min}$ at $60{ }^{\circ} \mathrm{C}$ (Tab. II).

Crude bacteriocin could be stored at $-30{ }^{\circ} \mathrm{C}$ or $4{ }^{\circ} \mathrm{C}$ for at least 3 and 2 months, respectively, without loss of activity. However, during storage at $25^{\circ} \mathrm{C}, 50 \%$ of activity was lost within 2 months (data not shown).

\subsection{Mode of action}

When the lower amount $\left(40 \mathrm{AU} \cdot \mathrm{mL}^{-1}\right.$ final inhibitory titer) of crude bacteriocin was added to exponentially growing $L$. lactis 
Table II. Effect of various treatments on inhibitory activity of crude bacteriocin from $S$. thermophilus ACA-DC 0001.

\begin{tabular}{lc}
\hline Treatment & Activity $^{*}$ \\
\hline Pronase & - \\
Trypsin & - \\
$\alpha$-Chymotrypsin & + \\
Protease & + \\
Proteinase & + \\
Pepsin & + \\
Ficin & + \\
Rennin & + \\
$\alpha$-Amylase & + \\
Lysozyme & + \\
Lipase & + \\
24 h pH $1-3$ & - \\
24 h pH $4-9$ & + \\
24 h pH $10-12$ & - \\
10 min $50{ }^{\circ} \mathrm{C}$ & + \\
10 min $60{ }^{\circ} \mathrm{C}$ & - \\
\hline
\end{tabular}

* the data represent the presence (+) and loss (-) of activity observed using the agar diffusion test with L. lactis ssp. cremoris CNRZ 117 used as bioassay strain.

ssp. cremoris CNRZ 117, growth stopped and the viability $\left(\mathrm{cfu} \cdot \mathrm{mL}^{-1}\right)$ dropped by $2 \log$ units within $24 \mathrm{~h}$ (Figs. 2a and 2b). At inhibitory titers of 80 and $160 \mathrm{AU} \cdot \mathrm{mL}^{-1}$, a drop in cfu. $\mathrm{mL}^{-1}$ of $4 \log$ units was observed during the first $2 \mathrm{~h}$ of incubation and growth was not resumed after prolonged incubation (Fig. 2b). Although the viability dropped dramatically upon addition of crude bacteriocin, the optical density of the sensitive culture did not decrease, suggesting that lysis did not occur (Fig. 2a).

Exposure of washed resting cells of L. lactis ssp. cremoris to $10240 \mathrm{AU} \cdot \mathrm{mL}^{-1}$ crude bacteriocin resulted in the killing of over $92 \%$ ( $1 \log$ reduction) of the cells within 5 min and $97 \%$ within 90 min (Fig. 3).

\subsection{Purification of thermophilin ST-1}

The results from the purification procedure are summarized in Table III. The mono-S cation-exchange and gel-filtration chromatographic elution profiles of the bacteriocin are shown in Figures $4 \mathrm{a}$ and $4 \mathrm{~b}$, respectively. The bacteriocin of $S$. thermophilus ACA-DC 0001 was recovered following $55 \%$ saturation of the culture broth with ammonium sulfate, with a simultaneous increase in its specific activity at 10970 (fraction II). Upon anionexchange chromatography on sepharose QHP, the bacteriocin was not bound and eluted during washing of the column with buffer $\mathrm{A}$ in a volume of $50 \mathrm{~mL}$. The specific activity at this stage was increased almost two-fold and the recovery was only $10 \%$ (Tab. III, fraction III). Following the concentration and buffer exchange of bacteriocin with the ultrafiltration procedure, a high specific activity of 29257 was achieved, but the yield was reduced to $4 \%$ (fraction IV). Then fraction IV was passed through a mono-S cation-exchange column, where a strong binding of activity was observed on the column (Fig. 4a). After elution of thermophilin ST-1, the specific activity was increased by fourhundred-fold followed by a low recovery of $0.8 \%$ (Tab. III, fraction V).

Upon size-exclusion chromatography, the majority of the bacteriocin activity was eluted in 2 fractions of $1 \mathrm{~mL}$ each, with a titer of $1280 \mathrm{AU} \cdot \mathrm{mL}^{-1}$. Finally, after this purification step, the specific activity increased five-hundred-fold with an overall recovery of bacteriocin at $0.1 \%$ (Tab. III, fraction IV). The elution volume (Ve) of thermophilin ST-1 activity from the superose 12 column corresponded to a molecular mass of ca. $30 \mathrm{~kg} \cdot \mathrm{mol}^{-1}$ (Fig. 4b).

\subsection{SDS-PAGE Electrophoresis}

SDS-PAGE of samples of the active size-exclusion chromatography fraction IV showed a protein band migrating close to the $29 \mathrm{~kg} \cdot \mathrm{mol}^{-1}$ marker, confirming the 

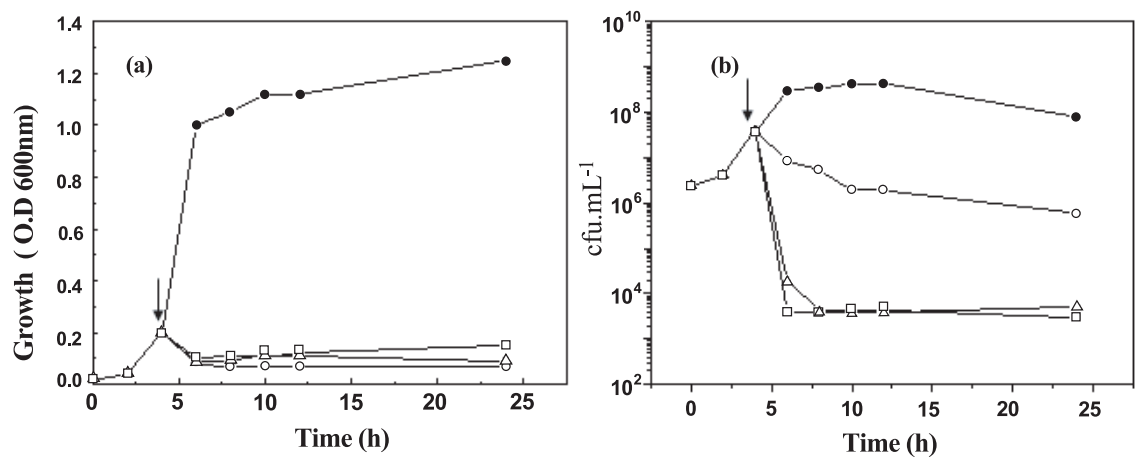

Figure 2. The effect of crude thermophilin ST-1 on (a) growth and (b) survival of sensitive strain L. lactis ssp. cremoris CNRZ 117 in Elliker broth at $37^{\circ} \mathrm{C}$. Thermophilin ST-1 concentrations of $(\bullet) 0 ;(\mathbf{O}) 40 ;(\triangle) 80$; and $(\square) 160 \mathrm{AU} \cdot \mathrm{mL}^{-1}$ were added to the growing culture at the beginning of the log growth phase $(\downarrow)$. During the incubation, optical density at $600 \mathrm{~nm}(\mathrm{OD})$ and viable cell counts were measured $\left(\mathrm{cfu} \cdot \mathrm{mL}^{-1}\right)$.

Table III. Purification of thermophilin ST-1.

\begin{tabular}{lcccccccc}
\hline $\begin{array}{l}\text { Purification } \\
\text { steps }\end{array}$ & $\begin{array}{c}\text { Fraction } \\
\text { No. }\end{array}$ & $\begin{array}{c}\text { Volume } \\
(\mathrm{mL})\end{array}$ & $\begin{array}{c}\text { Activity } \\
\left(\mathrm{AU} \cdot \mathrm{mL}^{-1}\right)\end{array}$ & $\begin{array}{c}\text { Total act. } \\
(\mathrm{AU}) *\end{array}$ & $\begin{array}{c}\text { Protein } \\
\left(\mathrm{mg} \cdot \mathrm{mL}^{-1}\right) *\end{array}$ & $\begin{array}{c}\text { Specific } \\
\text { activity } \\
\left(\mathrm{AU} \cdot \mathrm{mg}^{-1}\right) *\end{array}$ & $\begin{array}{c}\text { Recovery } \\
(\%) *\end{array}$ & $\begin{array}{c}\text { Purification } \\
(\text { fold }) *\end{array}$ \\
\hline $\begin{array}{l}\text { Culture } \\
\text { supernatant }\end{array}$ & I & 1000 & 2560 & 2560000 & 10 & 256 & 100 & 1 \\
$\begin{array}{l}\text { Ammonium } \\
\text { sulphate } \\
\text { precipitate }\end{array}$ & II & 20 & 15360 & 307200 & 1.4 & 10970 & 12 & 43 \\
$\begin{array}{l}\text { Sepharose } \\
\text { QHP }\end{array}$ & III & 50 & 5120 & 256000 & 0.4 & 12800 & 10 & 50 \\
$\begin{array}{l}\text { Ultrafiltrate } \\
\text { concentrated }\end{array}$ & IV & 10 & 10240 & 102400 & 0.35 & 29257 & 4 & 114 \\
$\begin{array}{l}\text { Mono-S } \\
\text { Superose-12 }\end{array}$ & V VI & 2 & 10240 & 20480 & 0.1 & 102400 & 0.8 & 400 \\
\hline
\end{tabular}

* Total activity is determined by the multiplication of Volume with Activity. Protein concentration was determined by BCA chromatometric method. Specific activity is activity units divided by the protein concentration $\left(\mathrm{AU} \cdot \mathrm{mg}^{-1}\right)$. Recovery is the remaining total activity as a percentage of the initial total activity. Purification fold is the increase of the initial specific activity.

molecular mass of thermophilin ST-1 obtained by the size-exclusion chromatography (Fig. 5).

\subsection{Plasmid analysis}

Plasmid analysis revealed that the original strain S. thermophilus ACA-DC 0001, wild-type, harbored one small plasmid of approximately $2.7 \mathrm{kbp}$ (Fig. 6, lane 2). Additional efforts were made to determine whether this plasmid carried genetic determinants responsible for thermophilin ST-1 production by incubating producer cells at $43{ }^{\circ} \mathrm{C}$ in the presence of acriflavine $\left(20 \mu \mathrm{g} \cdot \mathrm{mL}^{-1}\right)$. No mutants deficient in thermophilin ST-1 production (Ther-) were detected during examination of single colony 


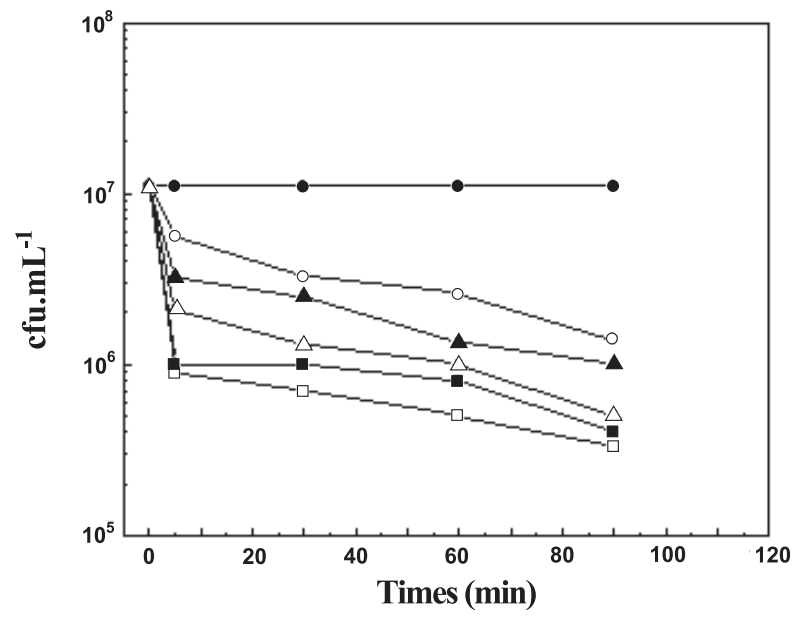

Figure 3. The effect of different concentrations of crude thermophilin ST-1 on L. lactis ssp. cremoris $\mathrm{CNRZ}$ 117 suspended in $5 \mathrm{mmol} \cdot \mathrm{L}^{-1}$ phosphate buffer, $(\mathrm{pH} 6.2)$ at

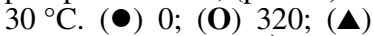

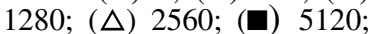
and (ㅁ) $10240 \mathrm{AU} \cdot \mathrm{mL}^{-1}$.

isolates for loss of the phenotype. Plasmid DNA isolations were performed on 8 Ther $^{+}$colonies isolated after growth of S. thermophilus ACA-DC 0001 in Elliker broth containing acriflavin $\left(20 \mu \mathrm{g} \cdot \mathrm{mL}^{-1}\right)$. Two of the Ther ${ }^{+}$isolates were found to be cured of the $2.7 \mathrm{kbp}$ plasmid, as is shown in Figure 6 (lanes 5 and 8).

\section{DISCUSSION}

The data derived from this study demonstrate that thermophilin ST-1, the bacteriocin isolated from the strain $S$. thermophilus ACA-DC 0001, has a wide antimicrobial spectrum including lactic acid bacteria and also a range of various Gram-positive and Gram-negative microorganisms. In general, among the LAB tested, lactobacilli were resistant to thermophilin ST-1, whereas lactococci and other $S$. thermophilus strains were the most sensitive. The resistance of lactobacilli to thermophilin ST-1 should exert a favorable effect on the synergistic interference of both these thermophilic microorganisms used for the production of yogurt and other fermented dairy products. The most notable inhibition was that against some potentially food-borne pathogenic bacteria such as E. faecalis, $L$. innocua and $S$. aureus strains; however, Clostridium sp. was not inhibited. Previous studies have shown that thermophilin 347 and thermophilin ST-13 exhibit an antilisterial activity $[18,36]$, whereas thermophilin $\mathrm{T}$ is inhibitory against Clostridium sp. [1]. However, the inhibitory spectrum of several thermophilins appears to be limited only to some closely related lactic acid bacteria $[5,9,38]$. In addition, this inhibitory ability of thermophilin ST-1 against Gram-negative phytopathogenic bacteria suggests that the producer strain could be used for the biological control of bacterial plant diseases, or for the control of postharvest plant diseases of fruit and vegetables under storage conditions. Similarly, a variety of lactic acid bacteria has also been reported to be antagonistic to test strains of the phytopathogens Xanthomonas campestris, Erwinia carotovora and Pseudomonas syringae [37].

Thermophilin ST-1 production was related to the growth phase of the culture and the highest titers were obtained during the early stationary phase, while further incubation caused a decay in the titer of activity. Similar results have been reported for thermophilin ST10 [5], thermophilin T [1] and thermophilin A [38]. On the contrary, 


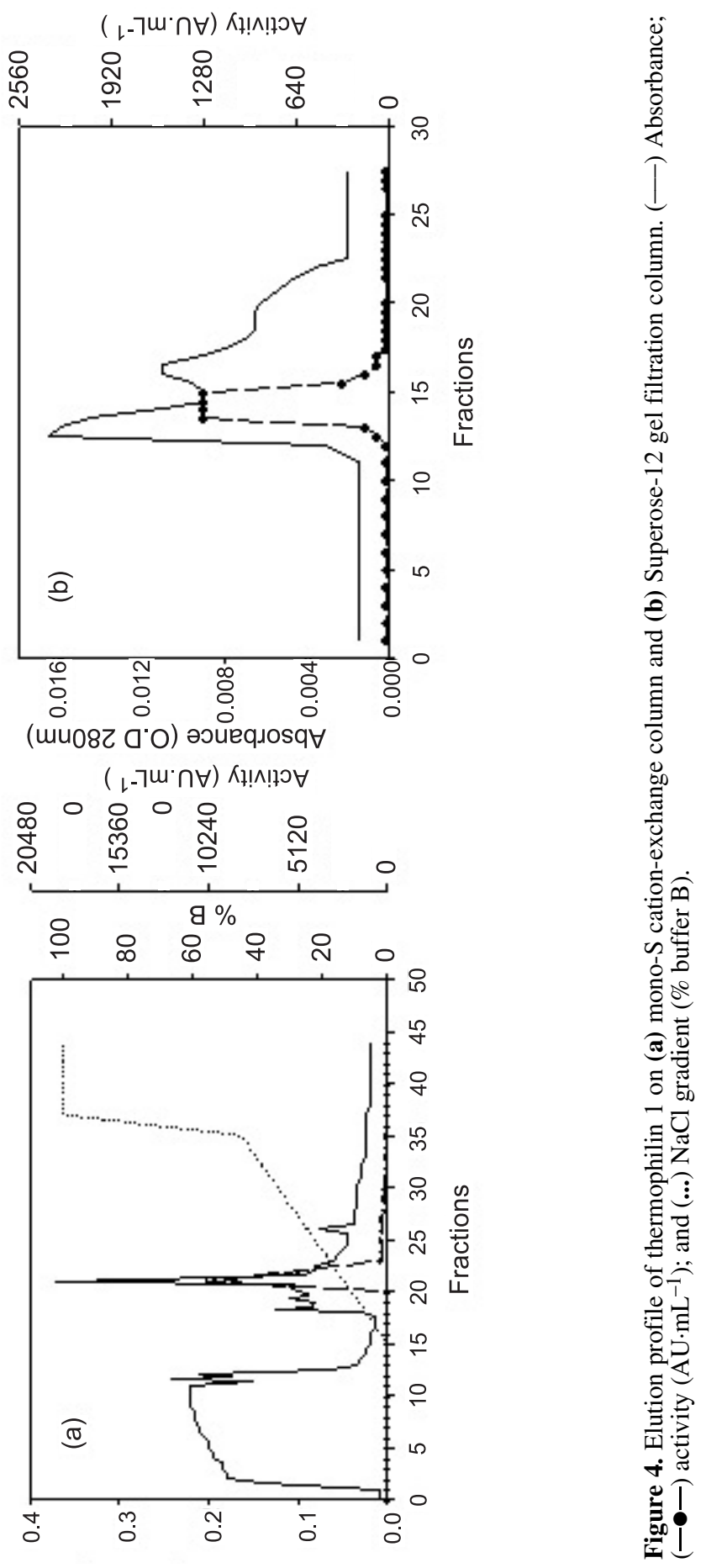




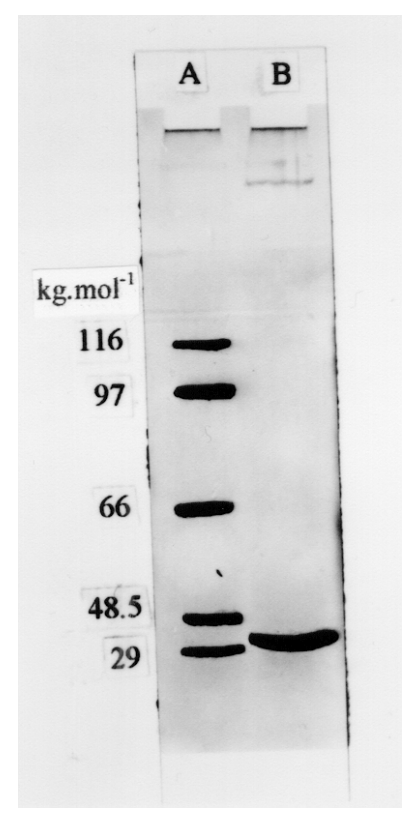

Figure 5. Tricine SDS-polyacrylamide gel elecrophoresis containing the molecular size marker (lane A); and the active fraction from Superose-12 gel-chromatography (lane B).

the maximum activity of thermophilin 347 was detected in the mid-log phase of growth and rapidly declined after further incubation [36].

The antibacterial activity of thermophilin ST-1 was completely eliminated by treatment with the pancreatic-originating proteolytic enzymes pronase and trypsin, suggesting its proteinaceous nature. In addition, its sensitivity to these enzymes suggests that it may be used as a biological preservative in foods and feeds, as it will not affect the microbial flora of the gastrointestinal tract. Similarly to thermophilin 13 and thermophilin $347[18,36]$, thermophilin ST-1 was not affected by $\alpha$-amylase and lipase. Conversely, thermophilin A [38], bacteriocin ST10 [5] and thermophilin T [1], also isolated from $S$. thermophilus strains, were sensitive to $\alpha$-amylase. The ability of thermophilin ST-1 to withstand inactiva-

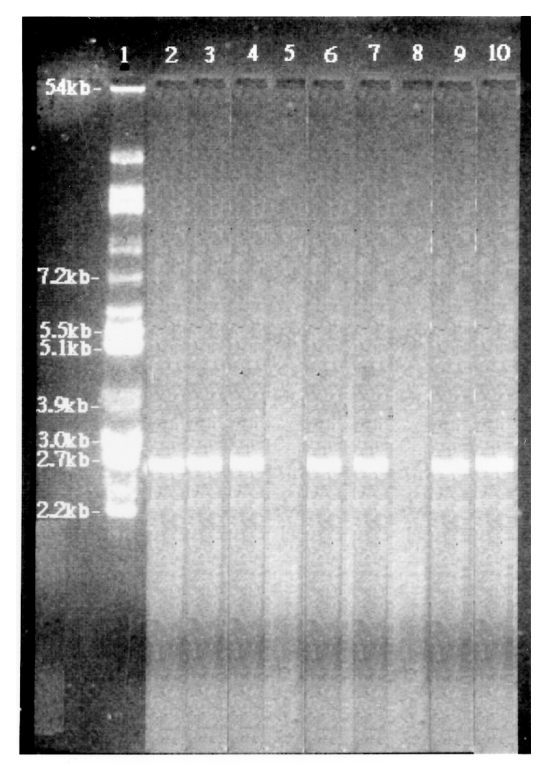

Figure 6. Agarose gel electrophoresis of plasmid DNA isolated from E. coli V517 (54, 7.2, 5.5, 5.1, 3.9, 3.0, 2.7 and $2.2 \mathrm{~kb}$ )(lane 1); $S$. thermophilus ACA-DC 0001 (lane 2); and eight $\left(\right.$ Ther $\left.^{+}\right)$S. thermophilus ACA-DC 0001 after acriflavin curing (lanes 3-8).

tion from rennin, makes it a more favorable agent for technological applications in cheese manufacturing.

The sensitivity of thermophilin ST-1 to heat $\left(60{ }^{\circ} \mathrm{C}\right.$ for $\left.10 \mathrm{~min}\right)$, acid and alkaline treatments suggests its proteinaceous structure of a large molecular mass. The molecular mass of $30 \mathrm{~kg} \cdot \mathrm{mol}^{-1}$, determined by size-exclusion chromatography and SDSPAGE electrophoresis, is consistent with the above biochemical properties of thermophilin ST-1 and classifies it as a large heatlabile protein, similar to helveticin J of $L b$. helveticus, acidophilucin A of Lb. acidophilus and lacticins A and B of Lb. delbrueckii ssp. bulgaricus $[13,15,34,35]$. On the contrary, other bacteriocins from different $S$. thermophilus strains such as thermophilin A [38], thermophilin 347 [36], thermophilin ST-13 [18] and thermophilin $\mathrm{T}$ [1] seem to be included in the non-lantibiotic heat-stable 
group of bacteriocins with small molecular mass. The above properties differentiate thermophilin ST-1 and make it unique.

Thermophilin ST-1 showed marked bactericidal action against the sensitive strain L. lactis ssp. cremoris CNRZ 117, which was concentration-dependent. Cell death was not associated with lysis or leakage of the cell membrane, since no changes in optical density were observed. This finding is consistent with other reports, suggesting that thermophilin $\mathrm{T}$, thermophilin A and several bacteriocins from different lactic acid bacteria can exert a similar effect [1, 13, 28, 38]. However, several bacteriocins causing lysis of sensitive cells have also been reported for several species of lactic acid bacteria [2, 23].

There are several reports of plasmidassociated bacteriocin production from lactic acid bacteria $[7,19,25]$, whereas in other cases, bacteriocin production has been linked to chromosomal DNA [14]. The results of this study suggest that the production of thermophilin ST-1 was not associated with a $2.7 \mathrm{~kb}$ plasmid, which is harbored in the $S$. thermophilus ACA-DC strain. In addition, the genetic stability of thermophilin ST-1 production, under growth conditions that induce plasmid curing, provides further evidence for chromosomalencoded thermophilin ST-1 production. Similar observations have also been reported for thermophilin A [38].

Futher work will be necessary to test the efficiency of thermophilin ST-1 against more undesirable bacteria in food and in the biological control of phytopathogenic bacteria in vivo. However, the broad inhibitory spectrum of thermophilin ST-1, its genetic stability and sensitivity to pancreatic enzymes may be considered as desirable properties for potential applications as a biopreservative agent.

\section{REFERENCES}

[1] Aktypis A., Kalantzopoulos G., Huis in't Veld J.H.J., ten Brink B., Purification and characterization of thermophilin $\mathrm{T}$, a novel bacteriocin produced by Streptococcus thermophilus ACA-DC 0040, J. Appl. Microbiol. 84 (1998) 568-576.

[2] Andersson R.E, Daeschel M.A., Hassan H.M., Antibacterial activity of plantaricin SIK-83, a bacteriocin produced by Lactobacillus plantarum, Biochimie 70 (1988) 381-390.

[3] Bhunia A.K., Johnson B.R., Ray B., Purification, characterization and antimicrobial spectrum of a bacteriocin produced by Pediococcus acidilactici, Appl. Bacteriol. 65 (1988) 261-268.

[4] Caro L., Churhward G., Chandler M., Study of plasmid replication in vivo, in: Bennett P.M., Grinsted J. (Eds.), Methods in Microbiology, Vol. 17, Academic Press, New York, USA, 1984, pp. 97-122.

[5] Cilano L., Bossi M.G., Carini S., Produzione di bacteriocine da parte di Streptococcus thermophilus, Microbiol. Alim. Nutr. 8 (1990) 21-30.

[6] Dajani A.S., Tom M.C., Law D.J., Viridins, bacteriocins of alpha-hemolytic streptococci: isolation, characterization and partial purification, Antimicrob. Agents Chemother. 9 (1976) 81-88.

[7] Davey G.P., Plasmid associated with diplococcin production in Streptococcus cremoris 346, Appl. Environ. Microbiol. 57 (1984) 895-896.

[8] Geis A., Singh J., Tueber M., Potential of lactic acid streptococci to produce bacteriocin, Appl. Environ. Microbiol. 45 (1983) 205-211.

[9] Germond J.E., Marciset O., Mollet B., Bacteriocins from Streptococcus thermophilus, PCT-Int. Patent Appl. WO95/06736 (1995).

[10] Green G., Dicks L.M.T., Bruggeman G., Vandamme E.J., Chikindas M.L., Pediocin PD-1, a bactericidal antimicrobial peptide from Pediococcus damnosus NCFB 1832, Appl. Microbiol. 83 (1996) 127-132.

[11] Huang J., Matthews H.R., Application of sodium dodecyl sulfate-gel electrophoresis to low molecular weight polypeptides, Anal. Biochem. 188 (1990) 114-117.

[12] Itoh I., Fujimoto Y., Kawai Y., Toba T., Saito T., Inhibition of food-borne pathogenic bacteria by bacteriocins from Lactobacillus gasseri, Lett. Appl. Microbiol. 21 (1995) 137-141.

[13] Joerger M.C., Klaenhammer T.R., Characterization and purification of helveticin $\mathrm{J}$ and evidence for a chromosomally determined bacteriocin produced by Lactobacillus helveticus 481, J. Bacteriol. 167 (1986) 439-446.

[14] Joerger M.C., Klaenhammer T.R., Cloning, expression, and nucleotide sequence of the 
Lactobacillus helveticus 481 gene encoding the bacteriocin helveticin J, J. Bacteriol. 172 (1990) 6339-6347.

[15] Klaenhammer T.R., Genetics of bacteriocins produced by lactic acid bacteria, FEMS Microbiol. Rev. 12 (1993) 39-86.

[16] Maniatis T., Fritsch E.F., Sambrook J., Molecular Cloning: Laboratory Manual, Cold Spring Harbor Laboratory, Cold Spring Harbor, New York, USA, 1982.

[17] Macrina F.L., Kopecko D.J., Jones K.R., Ayers D.J., Mc Cowen S.M., A multiple plasmid-containing Escherichia coli strain: convinient source of size reference plasmid molecules, Plasmid 1 (1978) 417-420.

[18] Marciset O., Jeronymus-Stratingh M.C., Mollet B., Poolman B., Thermophilin ST-13, a nontypical antilisterial poration complex bacteriocin, that functions without a receptor, J. Biol. Chem. 272 (1997) 14277-14284.

[19] Mortvedt C.I., Nes I.F., Plasmid associated bacteriocin production by a Lactobacillus sake strain, J. Gen. Microbiol. 136 (1990) 1601-1607.

[20] Ohmomo S., Murata S., Katayama N., Nitisinprasart S., Kobayashi M., Nakajima T., Yajima M., Nakanishi K., Purification and some characteristics of enterocin $\mathrm{ON}$ 157, a bacteriocin produced by Enterococcus faecium NIAI 157, Appl. Microbiol. 88 (2000) 81-89.

[21] Piard J.C., Delorme F., Giraffa G., Commissaire J., Desmazeaud M., Evidence for a bacteriocin produced by Lactococcus lactis CNRZ 481, Neth. Milk Dairy J. 44 (1990) 143-158.

[22] Pierce Chemical Company, BCA Protein Assay Reagent, Technical Bulletin 23225, Rockford III, USA, 1984.

[23] Pucci M.J., Vedamuthu E.R., Kinka B.S., Vanderbergh P.A., Inhibition of Listeria monocytogenes by using bacteriocin PA-1 produced by Pediococcus acidilactici, Appl. Environ. Microbiol. 4 (1988) 2349-2353.

[24] Pulusani S.R., Rao D.R., Sunki G.R., Antimicrobial activity of lactic cultures: partial purification and characterization of antimicrobial compounds produced by Streptococcus thermophilus, J. Food Sci. 44 (1979) 575-578.

[25] Ray S.S., Johnson M.C., Ray B., Bacteriocins plasmids of Pediococcus acidilactici, J. Ind. Microbiol. 4 (1989) 163-171.

[26] Rodriguez E., Gonzalez B., Gaya P., Nunez M., Medina M., Diversity of bacteriocins produced by lactic acid bacteria isolated from raw milk, Int. Dairy J. 10 (2000) 7-15.
[27] Schagger H., Von Jagow G., Tricine-sodium dodecyl sulfate-polyacrylamide gel electrophoresis for the separation of proteins in the range from 1 to $100 \mathrm{kDa}$, Anal. Biochem. 166 (1987) 368-379.

[28] Schillinger U., Lucke F.K., Antibacterial activity of Lactobacillus sake isolated from meat, Appl. Environ. Microbiol. 55 (1989) 1901-1906.

[29] Tagg J.R., Mc Given A.R., Assay system for bacteriocins, Appl. Microbiol. 21 (1971) 943-945.

[30] Ten Brink B., Huis in't Veld J.H.J., Comparison of the antimicrobial activities produced by the lactic acid bacteria studied in the ECBRIDGE programme, in: 4th Symposium on Lactic Acid Bacteria, Noordwijkerhout, The Nederlands, 1992.

[31] Ten Brink B., Minekus M., Van der Vossen J.M.B.M., Leer R.J., Huis in't Veld J.H.J., Antimicrobial activity of lactobacilli: preliminary characterization and optimization of production of acidocin $\mathrm{B}$, a novel bacteriocin produced by Lactobacillus acidophilus M46, Appl. Bacteriol. 77 (1994) 140-148.

[32] Thompson J.K., Collins M.A., Mercer W.D., Characterization of a proteinaceous antimicrobial produced by Lactobacillus helveticus CNRZ 450, Appl. Bacteriol. 80 (1996) 338-348.

[33] Thunell R.K., Sandine W.E., Types of starter cultures, in: Gilliland S.E. (Ed.), Bacterial starter cultures for foods, CRC Press, Boca Raton, USA, 1985, pp. 127-144.

[34] Toba T., Yoshioka E., Itoh T., Lacticin, a bacteriocin produced by Lactobacilus delbrueckii subsp. lactis, Lett. Appl. Microbiol. 12 (1991) 43-45.

[35] Toba T., Yoshioka E., Itoh T., Adidophilu$\operatorname{cin} \mathrm{A}$, a new heat labile bacteriocin produced by Lactobacillus acidophilus LAPT 1060 , Lett. Appl. Microbiol. 12 (1991) 106-108.

[36] Villani F., Pepe O., Mauriello G., Salzano G., Moschetti G., Coppola S., Antilisterial activity of thermophilin 347, a bacteriocin produced by Streptococcus thermophilus, Int. J. Food Microbiol. 25 (1995) 179-190.

[37] Visser R., Holzapfel W.H., Bezuidenhout J.J., Kotze J.M., Antagonism of lactic acid bacteria against phytopathogenic bacteria, Appl. Environ. Microbiol. 52 (1986) 552-555.

[38] Ward D.J., Somkuti G.A., Characterization of a bacteriocin produced by Streptococcus thermophilus ST134, Appl. Microbiol. Biotechnol. 43 (1995) 330-335. 